\title{
Analysis and prognosis of bitter acids content in Czech hop varieties - year 2020 and long-term comparisons and trends
}

\author{
Alexandr Mikyška ${ }^{1^{*}}$, Klára Belešová ${ }^{1}$, Jana Tichá ${ }^{2}$ \\ 1 Research Institute of Brewing and Malting, Lípová 511/15, \\ 12000 Prague 2, Czech Republic \\ 2 CHMELARSTVI, cooperative Žatec, Mostecká 2580, \\ 43801 Žatec, Czech Republic
}

* corresponding author: mikyska@beerresearch.cz

\begin{abstract}
The article deals with the harvest forecast of the content of bitter acids in Czech hop varieties harvested in 2020. This is presented in the context of long-term trends in the content and composition of bitter acids analogues and the stability of the varietal characteristics in the aforementioned harvest. This analysis is usually available at the end of the calendar year. 180 hop samples were analysed using EBC 7.7 (HPLC) method. The $a$-acids content in the most important variety of Saaz (3.65\% in dry matter) was $12.8 \%$ rel. higher than in the 2019 harvest and $4.2 \%$ rel. higher than the 28-year average. The $a$-acids content in Saaz Late (3.23\%), Sladek (7.9\%), Kazbek (6.4\%) and Agnus (12.4\%) was significantly higher than both the long-term averages for the varieties and the harvest of 2019. The Premiant (8.0\%) variety was close to the long-term average. The ratio of $\alpha-/ \beta$-acids, the relative content of cohumulone and the relative content of colupulone were consistent with long-term averages of the tested varieties. It was confirmed that the harvest forecast provides timely information on the $a$-acids content of the given harvest, the results being in good agreement with the values of the final evaluation of all harvested hops.
\end{abstract}

Key words: hops harvest, Saaz hops, Sladek, Premiant, Agnus, Kazbek, Saaz Late, alpha acids, beta acids

\section{Introduction}

This study presents a harvest forecast of the content of $\alpha$ and $\beta$-bitter acids in significant Czech hop cultivars from the harvest of 2020 in the context of long-term trends in the content of hop resins in Czech hops. The evaluation of the $\alpha$ - and $\beta$-bitter acids of the harvested hops at the Research Institute of Brewing and Malting (RIBM) is carried out yearly and has been done since 1950 . The analysed samples were collected during the course of the whole harvest from all three growing areas in the Czech Republic. The values provide a harvest prediction based on the analysis of 180-190 hop samples. The evaluation of the whole harvest for all the purchased batches of hops was performed by Chmelarstvi, cooperative Žatec and the Hop Research Institute, where both institutions used the lead conductance value.
In 2004, the RIBM began the evaluation of other Czech hop varieties called Sládek and Premiant which are important for domestic breweries. The Agnus variety has also been evaluated since 2009 , the aroma variety Kazbek since 2014. In 2015 the assessment of the aroma variety Saaz Late started. The last variety was recommended by the RIBM for beer production according to PGI Czech Beer in 2013 (Mikyška et al., 2013).

In 2020 the hop yard production areas in the Czech Republic amounted to 4,947 ha, which means a decrease of 56 ha compared to 2019. The total of 232 ha was planted within the frames of the continued renovation of older stands. The Žatec area (Saaz) spread over 3,815 ha, the Úštěk area (Auscha) 505 ha and the Tršice area (Tirschiz) 628 ha. The most important variety is 
still the Saaz variety, which was cultivated on $84.9 \%$ of all hop yards in the Czech Republic in 2020. Other Czech varieties Sládek, Premiant, Agnus, Kazbek and Saaz Late were cultivated on $7.4 \%, 3.9 \%, 1.1 \%, 0.6 \%$ and $0.9 \%$ of the hop yards, and thus represent only minor varieties (Chromý, 2021a).

The 2020 harvest yielded 5,925 tons of dried hops, i.e., by $17.6 \%$ lower than in 2019 and this is comparable to the harvest of 2018. The harvest yielded 4,323 tons of hops in the Žatec area, 726 tons in the Úštěk area and in the Tršice area the yield amounted to 876 tons. The average yield was 1.03 tons/ha (Chromý, 2021). Since 1994 the hop samples have been analysed using a highly specific HPLC method in accordance with Analytica-EBC (method 7.7.) for the determination of $\alpha$ - and $\beta$-bitter acids and their analogues (EBC Analyses Committee, 2010). In addition to the essential $\alpha$-bitter acids, also $\beta$-bitter acids are evaluated due to their partial effect on the bitterness of beer (Dušek et al., 2014; Algazzali and Shellhammer, 2016). Altogether, results from 28 years of hop quality testing in the Czech Republic by this method are available. It should be noted that the results obtained using different methods are not fully comparable. The values obtained by the lead conductance methods are generally higher than the values obtained by the HPLC method in accordance with Analytica EBC because the lead conductance value also covers additional components of the hop resins (Krofta et al., 2017).

The content and composition of hop resins as well as other secondary metabolites, that are crucial for the beer brewing and pharmaceutical industries, e.g. hop oils and polyphenols, are given primarily by genetically determined varietal specificity (Dressel et al., 2016). However, other factors such as aggregate soil and climatic conditions (Forster and Gahr, 2014; Forteschi et al., 2019), weather conditions during vegetation and harvest in the given year, soil conditions of the locality, age of hop plants and viral infections play also an important role (Jelínek et al., 2012; Kavalier et al., 2011). Polyphenol substances in the mass of hop cone are formed at earlier stages than the compounds contained in lupulin glands, resins, essential oils and prenylflavonoids. The course of weather at the time of hop growth and ripening together with the date of harvesting can substantially influence the content, composition and ratios of the secondary metabolites of hops (Kavalier et al 2011; Inui et al., 2017). It was also demonstrated that the composition of the essential oils and the pleasantness of the hop aroma is, in addition to the time of harvest, influenced by pruning time of hop plants (Inui et al., 2016). Thus, the reliability of the harvest prediction depends on the number and geographical distribution of hop samples included in the study.

\section{Material and Methods}

The samples of freshly harvested and dried hops were collected in collaboration with the Chmelarstvi, cooperative Žatec from batches supplied by Czech and Moravian hop producers during the harvest or immediately after the end of the harvest. The batches of hops dried on an industrial scale were sampled and transported to the RIBM. The number of samples corresponded to the harvest areas. The specific localities were selected in such a way so that the survey could cover all three growing areas, i.e. Žatec, Úštěk and Tršice. The analyses were conducted immediately after the delivery of the hop batches. The whole sample collection was analysed using the HPLC method in accordance with Analytica EBC, method 7.7 (EBC Analyses Committee, 2010) for the determination of $\alpha$ - and $\beta$ - bitter acids and their analogues. The water content was determined by drying $5 \mathrm{~g}$ of milled sample at the temperature of $105^{\circ} \mathrm{C}$ for 60 minutes.

\section{Results and Discussion}

The following text presents and interprets obtained contents of $\alpha$ - and $\beta$-bitter acids in well-established Czech hop varieties in the context of the past three decades. The first part is devoted to the dominant Saaz variety from all three Czech growing areas as well as from the point of view of the whole Czech Republic. An overview of five other varieties follows.

\subsection{Saaz Variety}

SAAZ VARIETY - ŽATEC GROWING AREA. All contents of bitter substances presented in this study are expressed as weight $\%$ in dry matter ( $\% \mathrm{w} / \mathrm{d}$.m.). The values obtained and their statistical evaluations are shown in Table 1 . The average content of $\boldsymbol{\alpha}$ - bitter acids in the hop samples examined from the Žatec area was 3.59\% (3.25\% in the original). This value was comparable to the long-term average of the last 28 years. The difference from the longterm average was $0.05 \%$ ( $11.4 \%$ rel.). In comparison to 2019 the content was higher by $0.27 \%$ (9.2\% rel.).

The overview of the $\alpha$ - and $\beta$-bitter acids contents in samples harvested over the last 28 years is shown in Figure 1 . The $\alpha$-and $\beta$-bitter acids content in the harvests from this period differed considerably. Year-on-year fluctuations caused by weather conditions during the vegetation and harvest of hops are clearly visible, but the trend is to decrease values due to other factors, especially global climate change. In terms of $\alpha$-acids content, the 1996, 2001, 2009 and 2011 harvests were strongly above average. On the contrary, the values for the 1994, 2006 and 2015 harvests were well below the long-term average. The yield of hops must 
Table 1 Bitter acids content of Saaz variety of year crop 2020 in the Žatec area

\begin{tabular}{|l|c|c|c|c|c|c|}
\hline & $\begin{array}{c}a \text {-acids } \\
\% \text { w/d.m. }\end{array}$ & $\begin{array}{c}\text { cohumulone } \\
\% \text { rel. }\end{array}$ & $\alpha$-/ $\beta$-acids & $\begin{array}{c}\beta \text {-acids } \\
\% \text { w/d.m. }\end{array}$ & $\begin{array}{c}\text { colupulone } \\
\% \text { rel. }\end{array}$ & $\begin{array}{c}\text { moisture } \\
\% \text { w }\end{array}$ \\
\hline \multicolumn{1}{|c|}{ Average } & 3.59 & 23.6 & 0.92 & 3.89 & 41.0 & 9.5 \\
\hline Maximum & 6.20 & 27.7 & 1.60 & 5.56 & 43.4 & 12.6 \\
\hline Minimum & 2.24 & 20.3 & 0.64 & 3.01 & 37.7 & 7.0 \\
\hline SD & 0.80 & 1.7 & 0.16 & 0.55 & 1.4 & 1.0 \\
\hline SD (\% rel.) & 22.3 & 7.3 & 17.3 & 14.1 & 3.4 & 10.4 \\
\hline Median & 3.33 & 23.4 & 0.88 & 3.78 & 40.8 & 9.5 \\
\hline
\end{tabular}

SD - standard deviation

$\%$ w/d.m. - weight \% in dry matter

Table 2 Bitter acids content of Saaz variety of year crop 2020 in the Úštěk area

\begin{tabular}{|l|c|c|c|c|c|c|}
\hline & $\begin{array}{c}a \text {-acids } \\
\% \text { w/d.m. }\end{array}$ & $\begin{array}{c}\text { cohumulone } \\
\% \text { rel. }\end{array}$ & $\alpha$-/ $\beta$-acids & $\begin{array}{c}\beta \text {-acids } \\
\% \text { w/d.m. }\end{array}$ & $\begin{array}{c}\text { colupulone } \\
\% \text { rel. }\end{array}$ & $\begin{array}{c}\text { moisture } \\
\% \text { w }\end{array}$ \\
\hline \multicolumn{1}{|c|}{ Average } & 3.34 & 23.3 & 0.90 & 3.77 & 41.3 & 10.2 \\
\hline Maximum & 5.62 & 25.5 & 1.78 & 5.09 & 43.8 & 11.8 \\
\hline Minimum & 2.22 & 20.6 & 0.67 & 2.49 & 38.1 & 8.3 \\
\hline SD & 0.98 & 1.4 & 0.26 & 0.84 & 1.7 & 0.9 \\
\hline SD (\% rel.) & 29.4 & 5.9 & 28.4 & 22.3 & 4.2 & 8.6 \\
\hline Median & 3.10 & 22.9 & 0.85 & 3.82 & 41.9 & 10.1 \\
\hline
\end{tabular}

$S D$ - standard deviation

$\%$ w/d.m. - weight $\%$ in dry matter

also be taken into account when evaluating the hop harvest. For example, in the 2016 harvest with a content of $\alpha$ - acids at the level of the long-term average, was the highest since 2000 in terms of yields $(7,712$ tons, 1.61 tons/ha) (Mikyška et al., 2017).

The harvest of 2020 was unbalanced. The relative standard deviation of $\alpha$-bitter acids content in the whole set of samples covering both standard and virus-free plants was $22.3 \%$ (values of $\alpha$-bitter acids varied from $2.24 \%$ to $6.20 \%$ ). The statistical distribution of the $\alpha$-acids contents (Figure 2) showed that majority of the samples, $35 \%$ rel., was in the range of $\alpha$-bitter acids content between $3.0-3.5 \%$

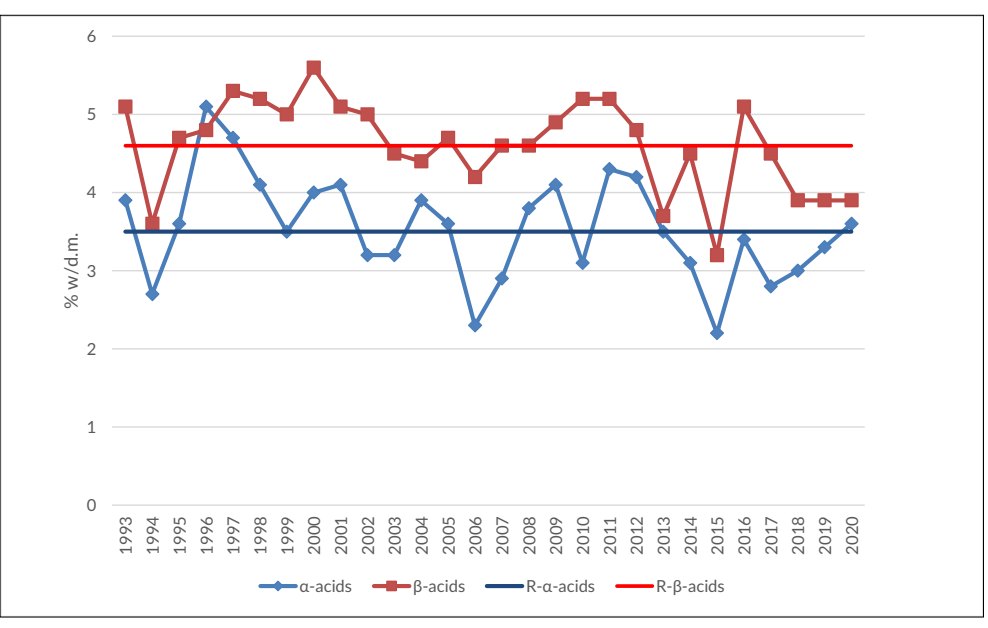

Figure 1 Bitter acids content of Saaz variety of year crops 1993-2020 in Žatec growing area

\begin{abstract}
while $91 \%$ of the samples had a content
\end{abstract} in the range of $2.5-5.0 \%$ by weight in dry matter.

The average content of $\boldsymbol{\beta}$-bitter acids of $\mathbf{3 . 8 9 \%}$ (3.52\% in the original) was comparable to the longterm average and $0.27 \%$ ( $9.1 \%$ rel.) higher than the average value from the harvest in 2019 . The ratio of $\alpha-/ \beta$ bitter acids was 0.92 . This value was higher compared to the average of the last 28 years (0.77).

Both the relative content of cohumulone in the total $\alpha$-bitter acids (23.6\% rel.) and the relative content of co- lupulone in the total $\beta$-bitter acids ( $41.0 \%$ rel.) were in the range typical for the Saaz variety and were about the same when compared to the long-term average of cohumulone (24.8\% rel.) and colupulone ( $40.6 \%$ rel.). The average water content in the tested samples was $9.5 \%$.

SAAZ VARIETY - ÚŠTĚK GROWING AREA. The average content of $\boldsymbol{\alpha}$-bitter acids in hop samples from the Úštěk area was $3.34 \%$ (2.99\% in the original) (Table 2). The 
harvest balance was worse than in Saaz growing area. The relative standard deviation for the values of $\alpha$-bitter acids in this group of samples was $29.4 \%$ and the values varied from $2.22 \%$ to $5.62 \%$. The average value for $\alpha$-bitter acids was comparable to the average for the last 28 years of monitoring (3.29\%) and $0.73 \%$ (36.5\% rel.) higher compared to 2019.

The content of $\boldsymbol{\beta}$-bitter acids of $3.77 \%(3.38 \%$ in the original) was $0.86 \%$ (18.5\% rel.) lower than the average for the last 28 years of monitoring and comparable to the harvest of 2019. The $\alpha$ - $/ \beta$-bitter acids ratio was 0.89 . This value was above the long-term average $(0.71)$ for this area.

Both the relative content of cohumulone in the total $\alpha$-bitter acids $(23.3 \%$ rel.) and the relative content of colupulone in the total $\beta$-bitter acids $(41.3 \%$ rel.) were almost identical to the long-term average values for this area $(24.5 \%$ rel. and $40.3 \%$ rel.). The average water content in the samples tested was $10.1 \%$.
SAAZ VARIETY - TRŠICE GROWING AREA. The average content of $\alpha$-bitter acids in hop samples from the Tršice area was $4.24 \%$ (3.85\% in the original) (Table 3 ). The harvest was more homogeneous than in the Saaz growing area. The relative standard deviation for the values of $\alpha$-bitter acids in

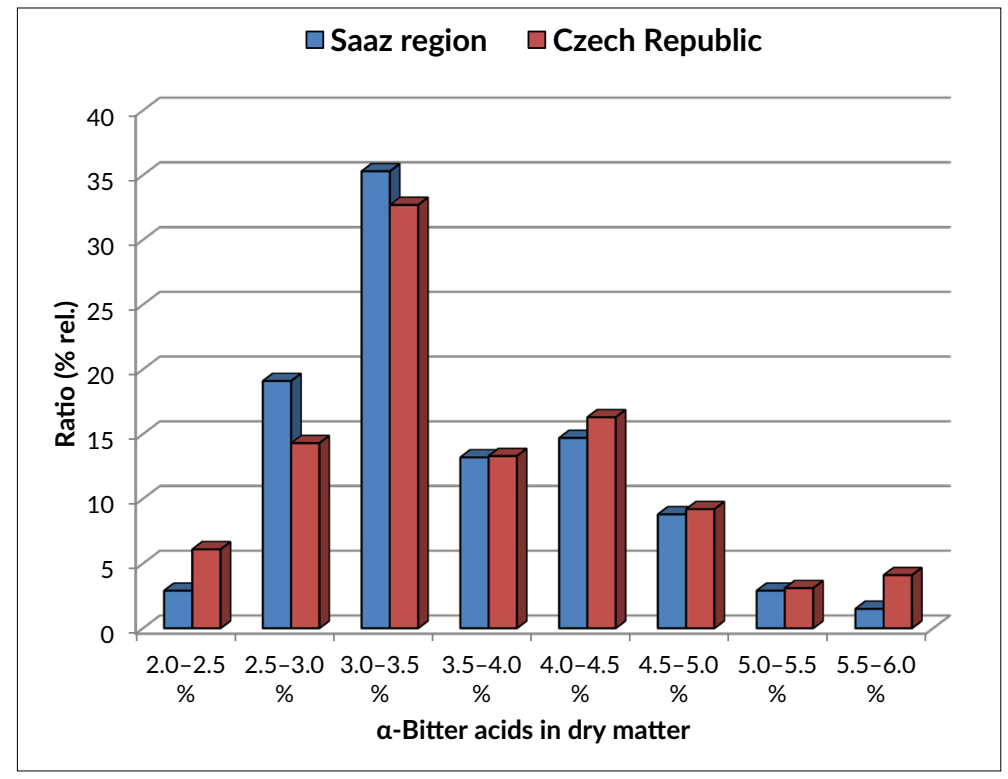

Figure 2 Distribution of $\alpha$-bitter acids content of Saaz hops harvested in 2020

Table 3 Bitter acids content of Saaz variety of year crop 2020 in the Tršice area

\begin{tabular}{|l|c|c|c|c|cc|c|}
\hline & $\begin{array}{c}a \text {-acids } \\
\% \text { w/d.m. }\end{array}$ & $\begin{array}{c}\text { cohumulone } \\
\% \text { rel. }\end{array}$ & $\alpha$-/ $\beta$-acids & $\begin{array}{c}\beta \text {-acids } \\
\% \text { w/d.m. }\end{array}$ & $\begin{array}{c}\text { colupulone } \\
\% \text { rel. }\end{array}$ & $\begin{array}{c}\text { moisture } \\
\% \text { w }\end{array}$ \\
\hline \multicolumn{1}{|c|}{ Average } & 4.24 & 24.5 & 0.98 & 4.31 & 40.4 & 9.3 \\
\hline Maximum & 5.71 & 29.5 & 1.20 & 5.23 & 42.8 & 10.3 \\
\hline Minimum & 3.20 & 19.4 & 0.79 & 3.61 & 37.8 & 8.4 \\
\hline SD & 0.80 & 2.5 & 0.12 & 0.45 & 1.3 & 0.5 \\
\hline SD (\% rel.) & 18.8 & 10.4 & 12.5 & 10.4 & 3.1 & 5.4 \\
\hline Median & 4.20 & 24.4 & 0.99 & 4.31 & 40.6 & 9.2 \\
\hline
\end{tabular}

SD - standard deviation

$\%$ w/d.m. - weight $\%$ in dry matter

Table 4 Bitter acids content of Saaz variety of year crop 2020 in the Czech Republic

\begin{tabular}{|l|c|c|c|c|cc|c|}
\hline & $\begin{array}{c}a \text {-acids } \\
\% \text { w/d.m. }\end{array}$ & $\begin{array}{c}\text { cohumulone } \\
\% \text { rel. }\end{array}$ & $\alpha$-/ $\beta$-acids & $\begin{array}{c}\beta \text {-acids } \\
\% \text { w/d.m. }\end{array}$ & $\begin{array}{c}\text { colupulone } \\
\% \text { rel. }\end{array}$ & $\begin{array}{c}\text { moisture } \\
\% \text { w }\end{array}$ \\
\hline \multicolumn{1}{|c|}{ Average } & 3.65 & 23.7 & 0.93 & 3.93 & 40.9 & 9.6 \\
\hline Maximum & 6.20 & 29.5 & 1.78 & 5.56 & 43.8 & 12.6 \\
\hline Minimum & 2.22 & 19.4 & 0.64 & 2.49 & 37.7 & 7.0 \\
\hline SD & 0.87 & 1.9 & 0.17 & 0.61 & 1.4 & 1.0 \\
\hline SD (\% rel.) & 23.9 & 7.9 & 18.8 & 15.6 & 3.5 & 10.0 \\
\hline Median & 3.38 & 23.4 & 0.89 & 3.85 & 40.8 & 9.6 \\
\hline
\end{tabular}

SD - standard deviation

$\%$ w/d.m. - weight \% in dry matter 
this group of samples was $18.8 \%$ and the values varied from $3.20 \%$ to $5.71 \%$. The content of $\alpha$-bitter acids was $0.89 \%$ (26.5\% rel.) higher compared to the average of the last 28 years and $0.49 \%$ (14.5\% rel.) higher than in 2019 (Table 2).

The content of $\boldsymbol{\beta}$-bitter acids in hops was $\mathbf{4 . 3 1 \%}$ (3.91\% in the original). This value was $0.18 \%$ ( $4.0 \%$ rel.) lower than the average of the last 28 years (3.34\%) and $0.19 \%$ ( $4.6 \%$ rel.) higher than the value of the harvest in the year 2019 . The $\alpha$ - $/ \beta$-bitter acids ratio was 0.98 . This value was lower than the long-term average (0.73).

Both the relative content of cohumulone in the total $\alpha$-bitter acids (24.5\% rel.) as well as the relative content of colupulone in the total $\beta$-bitter acids $(40.4 \%)$ were very similar to the long-term average values of this area (25.1\% rel. and $40.5 \%$ rel.). The average water content in the tested samples was $9.2 \%$.

SAAZ VARIETY - THE WHOLE OF THE CZECH REPUB-

LIC. The average content of $\alpha$-bitter acids in 100 samples of hops of standard and virus-free plants from the whole of the Czech Republic was 3.65\% (3.30\%

in the original) (Table 4). The average value was $0.15 \%$ ( $4.2 \%$ rel.) higher compared to the average for the last 28 years and $0.37 \%$ (12.8\% rel.) higher compared to the harvest of 2019 (Figure 3).

The harvest was more balanced than in 2019, when the relative standard deviation from the average content of $\alpha$-bitter acids was $36.5 \%$ while in 2020 it was $23.9 \%$ ( $\alpha$-acids in the range of $2.22-$ $6.20 \%$ ). The frequency distribution of the $\alpha$-acids content (Figure 2) shows the largest proportion of hops in the class ranging between 3.0-3.5 (32\%). In the adjacent classes between $2.5-3.0$ and 3.5-4.0 there was equally $14 \%$ samples and $25 \%$ of hops had a content ranging from 4.0 to $5.0 \%$ by weight in dry matter.
The average content of $\boldsymbol{\beta}$-bitter acids was $\mathbf{3 . 9 3 \%}$ (3.56\% in the original). It was $0.68 \%$ (14.7\% rel.) lower compared to the long-term average and similar to 2019.

The $\alpha$ - $/ \beta$-bitter acids ratio was 0.93 . This value was higher than the long-term average (0.75). Considerable superiority of $\beta$ - bitter acids was in the harvests 2006, 2007, 2010, 2014-2017, whereas the content of $\alpha$ - and $\beta$ - bitter acids nearly balanced for example in 2013 (Figure 3).

Both the relative content of cohumulone in the total $\alpha$-bitter acids (23.7\% rel.) and the relative content of colupulone in the total $\beta$-bitter acids (40.9\% rel.) were in the range typical for the Saaz variety and similar to the long-term average (cohumulone $24.7 \%$ rel., colupulone $40.4 \%$ rel.). The average water content was $9.6 \%$.

\subsection{Other Czech Varieties}

SLÁDEK VARIETY. The average content of $\boldsymbol{\alpha}$-bitter acids in the tested hop samples of the Sládek variety was $\mathbf{7 . 9 0 \%}$ (7.17\% in the original). The average content of the $\beta$-bitter acids was $4.51 \%$ (4.09\% in the original)

Table 5 Bitter acids content of Sládek variety of year crop 2020 in the Czech Republic

\begin{tabular}{|l|c|c|c|c|c|c|}
\hline & $\begin{array}{c}a \text {-acids } \\
\% \text { w/d.m. }\end{array}$ & $\begin{array}{c}\text { cohumulone } \\
\% \text { rel. }\end{array}$ & $\begin{array}{c}\alpha \text {-/ } / \text {-acids } \\
\text { Average }\end{array}$ & $\begin{array}{c}\beta \text {-acids } \\
\% \text { w/d.m. }\end{array}$ & $\begin{array}{c}\text { colupulone } \\
\% \text { rel. }\end{array}$ & $\begin{array}{c}\text { moisture } \\
\% \text { w }\end{array}$ \\
\hline Maximum & $\mathbf{7 . 9 0}$ & $\mathbf{2 5 . 9}$ & $\mathbf{1 . 7 9}$ & 4.51 & 50.7 & 9.2 \\
\hline Minimum & 10.93 & 29.1 & 2.61 & 5.37 & 52.9 & 10.7 \\
\hline SD & 5.51 & 23.1 & 1.23 & 3.26 & 48.4 & 7.5 \\
\hline SD (\% rel.) & 1.45 & 1.3 & 0.46 & 0.53 & 1.1 & 0.7 \\
\hline Median & 18.3 & 5.2 & 25.5 & 11.7 & 2.2 & 7.5 \\
\hline
\end{tabular}

$S D$ - standard deviation

$\%$ w/d.m. - weight \% in dry matter 
(Table 5). At the RIBM, the Sládek variety has been tested since 2004. However, the Sládek and Premiant varieties were not examined in 2007 due to an insufficient number of samples. The quality of the harvest of 2020 was strongly above the average in terms of the content of $\alpha$-bitter acids, $1.40 \%$ (21.5\% rel.) higher compared to the last 17 years average value and $2.99 \%$ (60.3\% rel.) higher than the values from 2019 . The content of $\beta$-bitter acids was $1.14 \%$ (20.1\% rel.) lower compared to the long-term average and 0.15 (4.0\% rel.) higher compared to the harvest in 2019 (Table 6).

The Hop Research Institute in Žatec declares a range from 4.5 to $8.0 \%$ as the typical content of the $\alpha$-acids and a range from 4.0 to $7.0 \%$ as the typical $\beta$-acids content in the Sládek variety (Nesvadba et al. 2012).

The relative standard deviation of $\alpha$-bitter acids values in this group of samples was $18.3 \%$. The $\alpha$-bitter acids content ranged from $5.51 \%$ to $10.93 \%$. Statistical distribution of the values showed the highest representation in the classes of $7.0-8.0 \%$ (28.0\% of samples) and $8.0-$ $9.0(32.0 \%$ of samples (Figure 4$)$.
The ratio $\alpha$-/ $\beta$-bitter acids was 1.79 , which is the range presented by the Hop Research Institute in Žatec ( 0.70 to 1.30 ). The relative content of cohumulone in the total $\alpha$-bitter acids $25.8 \%$ rel. and the relative content of colupulone in the total $\beta$-bitter acids $50.7 \%$ rel. were in the ranges given for this variety, i.e., values from 23 to $30 \%$ rel. for cohumulone and 44 to $50 \%$ rel. for colupu-

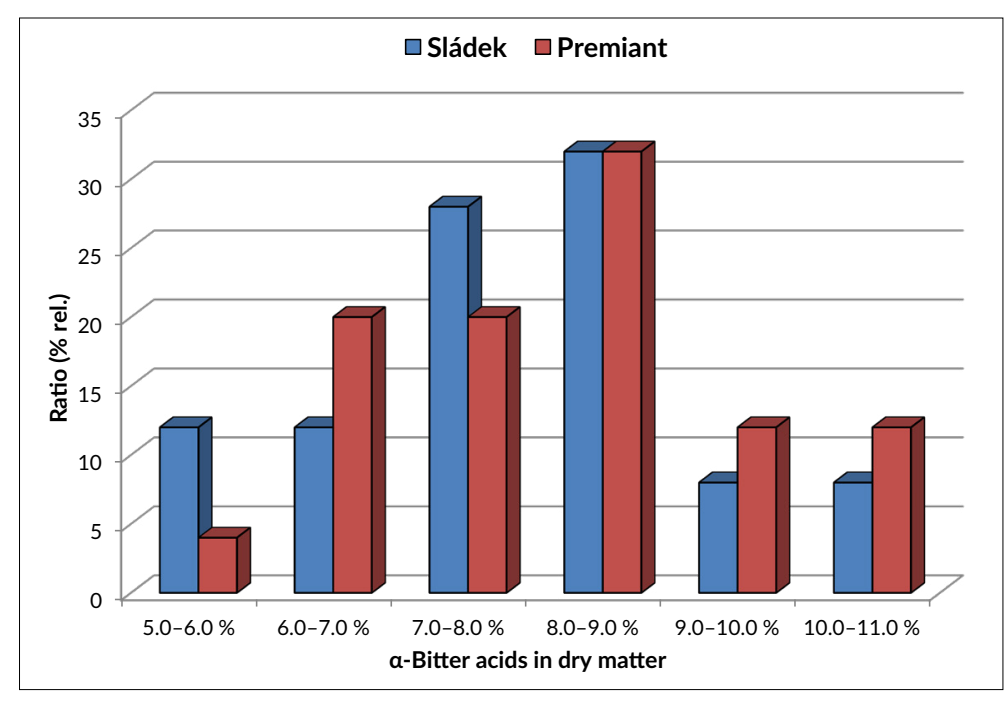

Figure 4 Distribution of $\alpha$-bitter acids content of Sládek and Premiant hops harvested in 2020

Table 6 Bitter acids content of Sládek, Premiant and Agnus varieties of year crops 2004-2020 in the Czech Republic (\% weight in dry matter)

\begin{tabular}{|c|c|c|c|c|c|c|}
\hline \multirow{2}{*}{ Variety } & \multicolumn{2}{|c|}{ Sládek } & \multicolumn{2}{c|}{ Premiant } & \multicolumn{2}{c|}{ Agnus } \\
\hline Year & a-acids & $\beta$-acids & $a$-acids & $\beta$-acids & a-acids & -acids \\
\hline 2004 & 5.8 & 5.5 & 9.8 & 4.4 & - & - \\
\hline 2005 & 6.8 & 7.1 & 9.0 & 5.3 & - & - \\
\hline 2006 & 6.5 & 6.5 & 7.6 & 6.0 & - & - \\
\hline 2007 & - & - & - & - & - & - \\
\hline 2008 & 6.6 & 6.1 & 10.2 & 4.8 & - & 6.6 \\
\hline 2009 & 7.3 & 7.2 & 11.0 & 5.1 & 13.5 & 7.1 \\
\hline 2010 & 7.3 & 6.4 & 9.7 & 5.9 & 11.2 & 6.1 \\
\hline 2011 & 8.2 & 5.8 & 10.1 & 5.2 & 11.0 & 6.0 \\
\hline 2012 & 7.0 & 5.2 & 8.9 & 5.1 & 12.1 & 5.6 \\
\hline 2013 & 6.2 & 5.1 & 8.4 & 4.2 & 11.2 & 6.2 \\
\hline 2014 & 5.8 & 6.1 & 7.2 & 5.8 & 9.7 & 4.9 \\
\hline 2015 & 5.1 & 4.4 & 6.6 & 3.3 & 10.5 & 6.3 \\
\hline 2016 & 7.3 & 6.4 & 9.0 & 5.5 & 9.7 & 6.3 \\
\hline 2017 & 6.4 & 5.9 & 7.7 & 5.7 & 11.0 & 5.2 \\
\hline 2018 & 5.0 & 3.7 & 4.7 & 3.5 & 10.9 & 5.2 \\
\hline 2019 & 4.9 & 4.4 & 6.6 & 4.3 & 10.7 & 4.8 \\
\hline 2020 & 7.9 & 4.5 & 8.0 & 3.4 & 12.4 & 5.9 \\
\hline Average & 6.5 & 5.7 & 8.4 & 4.8 & 11.1 & - \\
\hline & & & & & & \\
\hline
\end{tabular}


Table 7 Bitter acids content of Premiant variety of year crop 2020 in the Czech Republic

\begin{tabular}{|l|c|c|c|c|c|c|}
\hline & $\begin{array}{c}a \text {-acids } \\
\% \text { w/d.m. }\end{array}$ & $\begin{array}{c}\text { cohumulone } \\
\% \text { rel. }\end{array}$ & $\alpha$-/ $\beta$-acids & $\begin{array}{c}\beta \text {-acids } \\
\% \text { w/d.m. }\end{array}$ & $\begin{array}{c}\text { colupulone } \\
\% \text { rel. }\end{array}$ & $\begin{array}{c}\text { moisture } \\
\% \text { w }\end{array}$ \\
\hline \multicolumn{1}{|c|}{ Average } & 8.03 & 19.7 & 2.38 & 3.43 & 41.1 & 9.2 \\
\hline Maximum & 10.43 & 26.9 & 2.80 & 5.35 & 51.5 & 10.3 \\
\hline Minimum & 5.67 & 17.3 & 1.26 & 2.83 & 36.1 & 8.1 \\
\hline SD & 1.30 & 2.2 & 0.40 & 0.53 & 3.4 & 0.6 \\
\hline SD (\% rel.) & 16.2 & 11.0 & 16.9 & 15.4 & 8.3 & 6.3 \\
\hline Median & 8.16 & 19.4 & 2.52 & 3.33 & 40.3 & 9.2 \\
\hline
\end{tabular}

$S D$ - standard deviation

$\%$ w/d.m. - weight \% in dry matter

Table 8 Bitter acids content of Agnus variety of year crop 2020 in the Czech Republic

\begin{tabular}{|c|c|c|c|c|c|c|}
\hline & $\begin{array}{c}\text { a-acids } \\
\% \text { w/d.m. }\end{array}$ & $\begin{array}{c}\text { cohumulone } \\
\% \text { rel. }\end{array}$ & $a-/ \beta$-acids & $\begin{array}{c}\beta \text {-acids } \\
\% \text { w/d.m. }\end{array}$ & $\begin{array}{c}\text { colupulone } \\
\% \text { rel. }\end{array}$ & $\begin{array}{c}\text { moisture } \\
\% \mathrm{w}\end{array}$ \\
\hline Average & 12.41 & 30.6 & 2.57 & 4.85 & 53.4 & 9.0 \\
\hline Maximum & 15.56 & 33.3 & 2.93 & 6.28 & 55.1 & 9.9 \\
\hline Minimum & 10.44 & 23.9 & 2.18 & 4.19 & 47.4 & 8.1 \\
\hline SD & 1.73 & 2.9 & 0.21 & 0.71 & 2.5 & 0.6 \\
\hline SD (\% rel.) & 13.9 & 9.5 & 8.2 & 14.7 & 4.7 & 7.2 \\
\hline Median & 11.59 & 30.9 & 2.59 & 4.47 & 54.3 & 9.0 \\
\hline
\end{tabular}

SD - standard deviation

$\%$ w/d.m. - weight \% in dry matter

lone. They were also in agreement with the average from the last 17 years $(25.7 \%$ rel. and $48.7 \%$ rel.). The average water content was $9.2 \%$.

PREMIANT VARIETY. The average content of $\alpha$-bitter acids in the tested hops of the Premiant variety was $\mathbf{8 . 0 3 \%}$ (7.29\% in the original). The average content of $\beta$-bitter acids was $\mathbf{3 . 4 3 \%}$ (3.11\% in the original) (Table 7 ). The average $\alpha$-bitter acids content in the harvest of 2020 was lower by $0.38 \%$ ( $4.5 \%$ rel.) compared to the average for 17 years and by $1.38 \%$ (29.9\% rel.) higher than the harvest of 2019 . The $\beta$-bitter acids content was $1.49(21.1 \%$ rel.) lower than the long-term average and $0.82 \%(22.8 \%$ rel.) lower than the 2019 harvest (Table 6).

The Hop Research Institute in Žatec gives a range from 7 to $10 \%$ as typical for the $\alpha$-acids content and a range from 3.5 to $5.5 \%$ as typical for the $\beta$-acids content in the Premiant variety (Nesvadba et al. 2012).

The quality of Premiant hops in terms of $\alpha$-bitter acids content was relatively balanced; the relative standard deviation was $16.2 \%$. The $\alpha$-bitter acids content ranged from $5.67 \%$ to $10.43 \%$. Statistical distribution of values of $\alpha$-bitter acids content showed the highest representation in class $8.0-9.0$ (32\% of samples) while the other two classes, $7.0-8.0$ and $8.0-9.0$, included $20 \%$ of samples each (Figure 4).
The ratio of $\alpha$-/ $\beta$-bitter acids was 2.38 , which was at the upper limit of the range reported by the Hop Research Institute (1.70-2.30). The relative contents of cohumulone in the total $\alpha$-bitter acids $19.9 \%$ and of colupulone in the total $\beta$-acids $41.3 \%$ were in the range given for this variety (cohumulone 18-23\% rel. and colupulone $39-44 \%$ rel.). The average water content was $9.2 \%$.

AGNUS VARIETY. The average content of $\boldsymbol{\alpha}$-bitter acids in tested hop samples of the Agnus variety was $\mathbf{1 2 . 4 1 \%}$ (11.29\% in the original). The average content of $\boldsymbol{\beta}$-bitter acids was $4.85 \%$ (4.41\% in the original) (Table 8$)$. This variety has been evaluated at the RIBM for the 11 years. The $\alpha$-bitter acids content was 1.27 (11.4\% rel.) higher compared to the long-term average and 1.76 (16.1\% rel.) higher compared to the 2019 harvest. The content of $\beta$-bitter acids was 1.03 (17.5\% rel.) lower compared to the long-term average and comparable to the 2019 harvest (Table 6).

According to the Hop Research Institute in Žatec, the typical values of the $\alpha$-acids in the Agnus variety range from 9 to $12 \%$ whilst the typical values for the $\beta$-acids content vary from 4 to $6.5 \%$ (Nesvadba et al. 2012).

The $\alpha$ - $/ \beta$-bitter acids ratio was 2.57 . This value was in the referred range (1.90 to $2.60 \%$ ). The relative contents of cohumulone in the total $\alpha$-bitter acids (30.6\%) and of colupulone in the total $\beta$-bitter acids (53.4\%) were in the 
range specified for this variety (cohumulone between 29-38\% rel., colupulone between $51-59 \%$ rel.). The average water content was $9.0 \%$.

KAZBEK VARIETY. The average content of $\boldsymbol{\alpha}$-bitter acids in the tested hop samples of the Kazbek variety was $6.39 \%$ (5.81\% in the original). The average content of $\boldsymbol{\beta}$-bitter acids was $4.46 \%$ (4.06\% in the original) (Table 9). This variety has been evaluated at the RIBM for the 7 years. The content of $\alpha$-bitter acids was $1.41 \%$ (28.3\% rel.) higher than the seven-year average, compared to the harvest of 2019 was $2.11 \%$ ( $45.1 \%$ rel.) higher. The content of $\beta$-bitter acids was $0.37 \%$ ( $7.6 \%$ rel.) lower than the seven-year average. The difference from 2019 was similarly small (Table 7).

According to the Hop Research Institute in Žatec, typical values of the $\alpha$-bitter acids in the Kazbek variety range from 5 to $8 \%$ whilst typical values for the $\beta$-acids content vary from 4 to $6 \%$ (Nesvadba et al. 2012).

The $\alpha$-/ $\beta$-bitter acids ratio was 1.43 . This value was in the usual range $(0.90$ to $1.50 \%)$. The relative contents of cohumulone in the total $\alpha$-bitter acids (36.6\%) and of colupulone in the total $\beta$-bitter acids (60.8\%) were in the range specified for this variety (cohumu- lone between $35-40 \%$ rel., colupulone between $57-$ $62 \%$ rel.). The average water content was $9.0 \%$.

SAAZ LATE VARIETY. The average content of $\boldsymbol{\alpha}$-bitter acids in tested hop samples of the Saaz Late variety was $3.23 \%$ (2.93\% in the original) The average content of $\boldsymbol{\beta}$-bitter acids was $\mathbf{3 . 8 7 \%}$ (3.47\% in the original) (Table 10$)$. The $\alpha$-bitter acids content was $0.43 \%$ (15.2\% rel.) higher than the six-year average and $1.11 \%$ (70.8\% rel.) higher compared to the harvest of 2019. The $\beta$-bitter acids content was $0.35 \%$ ( $8.1 \%$ rel.) higher than the six-year average and $0.81 \%$ (21.6\% rel.) higher compared to 2019 .

According to the Hop Research Institute in Žatec, the typical values of the $\alpha$-bitter acids in the Saaz Late variety range from 3.5 to $6.0 \%$ whilst the typical values for the $\beta$-acids content vary from 4.0 to $6.5 \%$ (Nesvadba et al., 2012).

The $\alpha$ - $/ \beta$-bitter acids ratio was 0.69 . This value was below the lower limit of the range referred ( 0.8 to $1.0 \%$ ). The relative contents of cohumulone in the total $\alpha$-bitter acids $(25.3 \%)$ and the content of colupulone in the total $\beta$-bitter acids $(41.7 \%)$ was in the range specified for this variety (cohumulone between 20-25\% rel., colupulone between $39-43 \%$ rel.). The average water content was $8.4 \%$.

Table 9 Bitter acids content of Kazbek variety of year crop 2020 in the Czech Republic

\begin{tabular}{|l|c|c|c|c|c|c|}
\hline & $\begin{array}{c}\alpha \text {-acids } \\
\% \text { w/d.m. }\end{array}$ & $\begin{array}{c}\text { cohumulone } \\
\% \text { rel. }\end{array}$ & $\alpha$-/ $\beta$-acids & $\begin{array}{c}\beta \text {-acids } \\
\% \text { w/d.m. }\end{array}$ & $\begin{array}{c}\text { colupulone } \\
\% \text { rel. }\end{array}$ & $\begin{array}{c}\text { moisture } \\
\% \text { w }\end{array}$ \\
\hline \multicolumn{1}{|c|}{ Average } & 6.39 & 34.6 & 1.44 & 4.46 & 60.8 & 9.0 \\
\hline Maximum & 7.41 & 36.2 & 1.52 & 5.06 & 63.4 & 9.9 \\
\hline Minimum & 5.84 & 30.9 & 1.29 & 4.01 & 56.9 & 8.3 \\
\hline SD & 0.49 & 1.6 & 0.06 & 0.32 & 2.2 & 0.5 \\
\hline SD (\% rel.) & 7.6 & 4.5 & 4.3 & 7.1 & 3.6 & 5.9 \\
\hline Median & 6.44 & 35.0 & 1.46 & 4.49 & 61.2 & 9.1 \\
\hline 7-year average & 5.07 & 35.8 & 1.05 & 4.87 & 60.0 & 9.0 \\
\hline
\end{tabular}

$S D$ - standard deviation

$\%$ w/d.m. - weight \% in dry matter

Table 10 Bitter acids content of Saaz Late variety of year crop 2020 in the Czech Republic

\begin{tabular}{|l|c|c|c|c|c|c|}
\hline & $\begin{array}{c}\alpha \text {-acids } \\
\% \text { w/d.m. }\end{array}$ & $\begin{array}{c}\text { cohumulone } \\
\% \text { rel. }\end{array}$ & $\alpha$-/ $\beta$-acids & $\begin{array}{c}\beta \text {-acids } \\
\% \text { w/d.m. }\end{array}$ & $\begin{array}{c}\text { colupulone } \\
\% \text { rel. }\end{array}$ & $\begin{array}{c}\text { moisture } \\
\% \text { w }\end{array}$ \\
\hline \multicolumn{1}{|c|}{ Average } & 3.23 & 25.4 & 0.69 & 4.75 & 41.7 & 9.3 \\
\hline Maximum & 4.47 & 28.7 & 0.83 & 6.01 & 45.2 & 10.3 \\
\hline Minimum & 2.64 & 23.6 & 0.59 & 3.28 & 32.2 & 7.9 \\
\hline SD & 0.55 & 1.5 & 0.07 & 0.90 & 3.5 & 0.7 \\
\hline SD (\% rel.) & 17.0 & 5.7 & 10.7 & 18.9 & 8.5 & 7.4 \\
\hline Median & 3.11 & 25.2 & 0.69 & 4.52 & 42.4 & 9.0 \\
\hline 6-year average & 2.88 & 24.2 & 0.62 & 4.48 & 39.9 & 8.9 \\
\hline
\end{tabular}

$S D$ - standard deviation

$\%$ w/d.m. - weight \% in dry matter 


\section{Conclusions}

In 2020, 180 samples of freshly harvested dried hops were collected during or immediately after the harvest and analysed for $\alpha$ - and $\beta$-bitter acids, including their analogues. Analyses were performed according to the EBC methodology (Method 7.7), in the same way as in the last 28 years. The evaluated harvest was of good quality in terms of the bitter acids content. The most important variety of Saaz maintains its quality. The average content of $\alpha$-bitter acids (3.65\% w/d.m.) was $0.15 \%$ ( $4.2 \%$ rel.) higher than the average for the last 28 years and $0.37 \%$ (12.8\% rel.) higher compared to the harvest of 2019. Even better results were determined for the other tested varieties, where the average values of $\alpha$-bitter acids of the Saaz Late, Sládek, Kazbek and Agnus varieties were several tens of percent higher both compared to the long-term averages and to the year 2019. The value for Premiant was practically identical to the long-term average.

The ratio of $\alpha$-acids to $\beta$-acids, the relative content of cohumulone in total $\alpha$-acids and the relative content of colupulone in total $\beta$-acids were consistent with longterm averages for the tested varieties.

The results of our (RIBM) harvest forecast of the $\alpha$-bitter acids in the Saaz hops (3.25\% in the original) are in a relatively good agreement with the values of pre-harvest sampling (Žatec region 3.86\% in the original) and the overall evaluation of all purchased samples (Žatec region 3.85\% in the original) performed by Hop Research Institute (HRI) (Krofta et al., 2021). The reason for the lower values of the RIBM harvest forecast compared to the results published by the HRI rests on the use of different methods; the lead conductance method, according to Czech Technical Standard (ČSN 462520-15) that was used for the pre-harvest sampling as well as the overall evaluation of the harvest. The results of measurement by lead conductance methods are generally higher than those obtained by HPLC.

The $\alpha$-bitter acids content of other Czech varieties predicted by the RIBM was in good agreement with the results of the overall harvest evaluation, especially taking into account the different methods of analysis, as can be seen from the following comparison of the results of the two harvest evaluations, where the value after the slash is the result of HRI: Sladek (7.9/7.3\%), Premiant (8.0/8.1\%), Agnus (12.4/13.0\%), Kazbek (6.4/6.3\%) and Saaz Late (3.2/3.3\%) (Krofta et al., 2021).

\section{Acknowledgements}

This study was supported by the Ministry of Agriculture of the Czech Republic within the Institutional support MZE-R01918.

\section{References}

Algazzali, V., Shellhammer, T. (2016). Bitterness Intensity of Oxidized Hop Acids: Humulinones and Hulupones. Journal of the American Society of Brewing Chemists, 74(1), 36-43. https://doi.org/10.1094/ASBCJ-2016-1130-01

Chromý, Z. (2021). České chmelařství v přehledech ÚKZÚZ. Chmelařská ročenka 2021, VÚPS, Praha, 296-321. ISBN 978-80-86576-92-3. Available only in Czech.

Chromý, Z. (2021a). Odrůdová skladba chmele. Chmelařská ročenka 2021, VÚPS, Praha, 322-324 ISBN 978-80-86576-92-3. Available only in Czech.

ČSN 462520 (1997). Czech Technical Standard - Hops Testing part 15: Determination of lead conductance value of hops. Czech Standards Institute. Available only in Czech.

Dresel, M., Vogt, C., Dunkel, A., Hofmann, T. (2016). The Bitter Chemodiversity of Hops (Humulus lupulus L.). Journal of Agricultural and Food Chemistry, 64, 7789-7799. https://doi.org/10.1021/acs.jafc.6b03933

Dušek, M., Olšovská, J., Krofta, K., Jurková, M., Mikyška, A (2014). Qualitative determination of $\beta$ acids and their transformation products in beer and hop using HR/AM-LC-MS/MS. Journal of Agricultural and Food Chemistry, 62, 7690-7697. https://doi.org/10.1021/jf501852r

EBC Analysis committee (2010). Analytica-EBC. Nürenberg, Fachverlag Hans Carl, pp. 794. ISBN 978-3-418-00759-5

Forster, A., Gahr, A. (2014). A Comparison of the Analytical and Brewing Characteristics of Cascade and Comet Hop Varieties as Grown in Yakima (USA) and Hallertau (Germany). Brewing Science, 67(11/12), 138-148.

Forteschi, M., Porcu, M.C., Fanari, M., Zinellu, M., Secchi, N., Buiatti, S., Passaghe, P., Bertoli, S., Pretti, L. (2018). Quality assessment of Cascade Hop (Humulus lupulus L.) grown in Sardinia. European Food Research and Technology, 245, 863-871. https://doi.org/10.1007/ s00217-018-3215-0

Inui, T., Matsui, H., Hosoya, T., Kumazawa, S., Fukui, N., Oka, K. (2016). Effect of Harvest Time and Pruning Date on Aroma Characteristics of Hop Teas and Related Compounds of Saaz Hops. Journal of the American Society of Brewing Chemists, 74(4), 231-241. https://doi. org/10.1094/ASBCJ-2016-4628-01

Inui, T., Okumura K., Matsui, H., Hosoya, T., Kumazawa, S. (2017). Effect of harvest time on some in vitro functional properties of hop polyphenols. Food Chemistry, 225, 69-75. https://doi.org/10.1016/j.foodchem.2017.01.002

Jelínek, L., Dolečková, M., Karabin, M., Hudcová, T., Kotlíková, B., Dostálek, P. (2012). Influence of growing area, plant age, and virus infection on the contents of hop secondary metabolites. Czech Journal of Food Sciences, 30, 541-547. https://doi.org/10.17221/50/2012-CJFS

Kavalier, A.R., Litt, A., Ma, C., Pitra, N.J., Coles, M.C., Kennelly, E.J., Matthews, P.D. (2011). Phytochemical and Morphological Characterization of Hop (Humulus lupulus L.) Cones over Five Developmental Stages Using High Performance Liquid Chromatography Coupled to Timeof-Flight Mass Spectrometry, Ultrahigh Performance Liquid Chromatography Photodiode Array Detection, and Light Microscopy Techniques. Journal of Agricultural and Food Chemistry, 59, 4783-4793. https://doi.org/10.1021/jf1049084

Krofta, K., Klapal, I., Fritschová, G., Vojtěchová, D., Tichá, J. (2021). Hodnocení kvalitativních ukazatelů českých chmelů ze sklizně 2020 (Evaluation of qualitative indicators of Czech hops from the 2020 harvest). Chmelařství, 94(1-2), 8-13. Available only in Czech.

Krofta, K., Mikyška, A., Jurková, M., Mravcová, L., Vondráčková, P. (2017). Determination of Bitter Compounds in Hops - Effect of Crop Year and Hops Age. Kvasny prumysl, 63(5), 241-247. https://doi. org/10.18832/kp201725 
Mikyška, A., Dušek, M. , Jurková, M. (2017). Evaluation of $\alpha$ - and $\beta$-bitter Acids Content in Harvest of Czech Hops in 2016. Kvasny prumysl, 63(4), 190-198. https://doi.org/10.18832/kp201721

Mikyška, A., Slabý, M., Jurková, M., Krofta, K., Patzak, J., Nesvadba, V. (2013). Saaz-Late - the Czech hop variety recommended for Czech beer. Kvasny prumysl, 59(10-11), 296-305. https://doi.org/10.18832/ kp2013031
Nesvadba, V., Polončíková, Z., Henychová, A., Krofta, K., Patzak, J. (2012). Czech hop varieties. Chmelařský institut s.r.o.. Žatec. ISBN 978-8087357-11-8. 